\title{
Studying the Effect of Different RPD Design and Materials on Reduced Bone Support, a FEA study \\ Wasmaa S. Mahmood
}

Assist. Prof

Souza A. Azziz

Prof.

Imad A. Jebouri

Prof.

Aim of the study: To study the effect of reduced level of bone support on stress concentration and distribution. Also comparing the effect of different metals (gold, cobalt-chromium, and titanium) on alveolar supporting bone.

Material and methods: A FEA method is used on a reduced bone support class I Kennedy classification, with three different rest positions (mesial, distal, mesial and distal) Co-Cr partial denture; Then changing the modulus of elasticity of the chrome-cobalt, to study the effect of gold and titanium alloy on the supporting bone surrounding the abutment in terms of stress distribution. Results: results revealed that best design type is by placing mesial and distal rest on abutment, also when comparing the three types of metals (Co-Cr, titanium, gold), there was no significant difference among the three metals.

دراسة تاثير استخدام الطقم الجزئي المتحرك على العظم المنحسر مع تغيير نوع المواد و التصميم. طريقة العناصر المحددة لتحليل الاجهاد

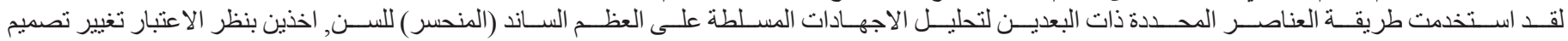

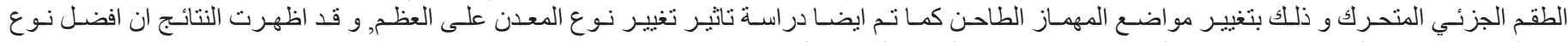

\section{INTRODUCTION}

The phenomenon of mandibular residual ridge resorption in edentulous patients is currently considered a serious clinical issue;

It is a chronic, progressive, irreversible, and cumulative process characterized by sequential stages that first affect buccal and lingual surfaces and, eventually, the alveolar bone crest ${ }^{(1)}$.

Progressive bone loss without proper prosthetic treatment and rehabilitation of the masticatory organ can contribute to numerous unfavorable results. Tooth loss cause masticatory impairment as well as loss of periodontal tissue receptors, which play a significant regulatory role in the function of the masticatory organ. The efficiency of mastication is thus markedly decreased. Apart from this, it can alter the nutrition habits of the elderly in favor of a highfat diet, avoidance of fiber, raw vegetables and fruit. As a result, a deterioration in general condition and an increased risk of cardiovascular and neoplastic disease can occur $^{(2)}$. The continual resorption of the residual ridge negatively impacts the stability, retention and support of RPDs, thus placing patients in a loop of continual change towards inferior stability and discomfort ${ }^{(3,4,5)}$ Furthermore occlusal forces must be considered to be the major cause of RRR because these forces are able to cause rapid and thorough resorption without systemic bone loss ${ }^{(6)}$ This why this study was conducted to find out the best possible denture design with least harmful effect on underlying bone

\section{MATERIALS AND METHODS}

A stone cast model was fabricated (30mg powder,
$100 \mathrm{mg}$ water), trimming fist and second molars, then a $\mathrm{Co}-\mathrm{Cr}$ framework was constructed to simulate a free end class I partial denture with lower second premolar as the primary abutment. Each component of the model was transferred exactely to the ANSYS programme; the 2-D model was formed as in figure (1)

Atwo dimensional strain mesh of the mandibular second permanent premolar with its supporting structures, distal extension RPD, and bone forming part of the mandible.

for reduced bone support, crown/root ratio is (1/0.7)7The table below show the three different rest seat positions,

Table (1 ) represents the symbols and designs of the FEM

RE-D reduced bone support, distal rest.

RE-M reduced bone, mesial rest.

RE-MD reduced bone support, mesial-distal rest.

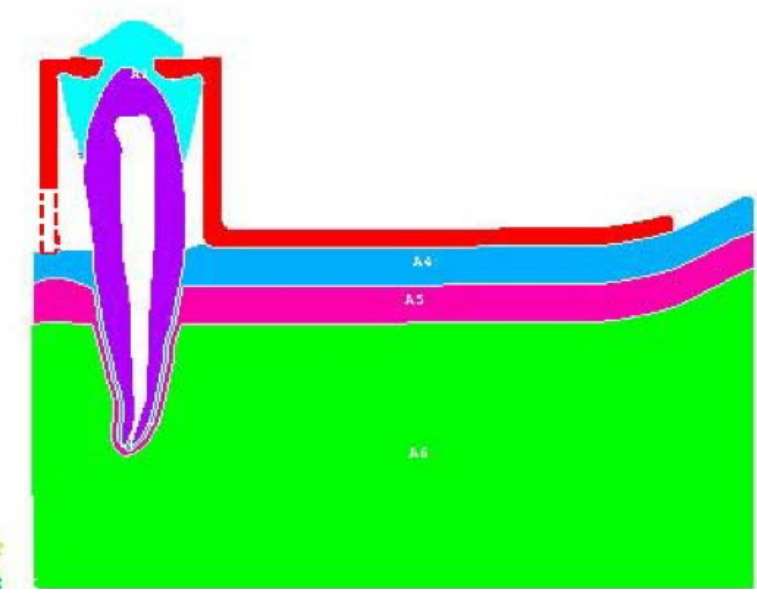

Fig (1): Schematic drawing of the 2-D model in reduced bone support 
Material properties:

metal is by changining the Young's Modulous and for measuring the effect of different types of Poisson's ratio as the table below.

Table (2): The proper value of the Young's Modulus," $E$ " and, Poisson's ratio "V" are shown in Table (2).

\begin{tabular}{|c|c|cc|}
\hline Materials & Young's modulus (Mpa) & \multicolumn{2}{|c|}{ Poisson's ratio } \\
\hline Co-Cr.Alloy & 218000 & 0.33 & $(8)$ \\
\hline Enamel & 84000 & 0.33 & $(8)$ \\
\hline Dentine & 18600 & 0.31 & $(8)$ \\
\hline PDL & 3.45 & 0.45 & $(8)$ \\
\hline Cortical bone & 13000 & 0.3 & $(9)$ \\
\hline Cancellous bone & 1000 & 0.3 & $(9)$ \\
\hline Gold & 99300 & 0.33 & $(10)$ \\
\hline Titanium & 110000 & 0.33 & $(10)$ \\
\hline
\end{tabular}

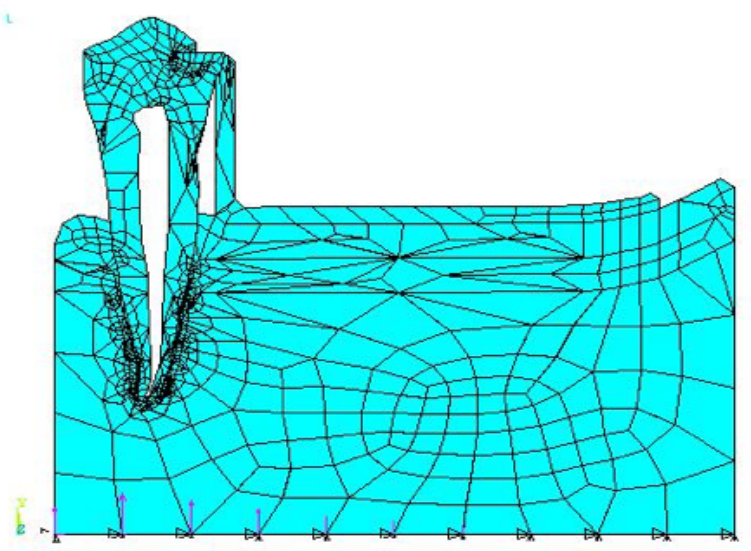

Fig (2): Shows 2-D plaine strain mesh in reduced bone support

therefore, a key step in the analysis,

A fine mesh of the Finite Element model was generated using the quadrilateral 8-node, as shown in Figures (2), which is a higher order version of the 2D-4-node element; it provides more accurate results and can tolerate irregular shapes without as much loss of accuracy.

The 8-node elements have compatible displacement shapes and are well suited to model Curved boundaries.

8 nodes elements having two degree of freedom at each node define the 8-node element Translations in the nodal $\mathrm{X}$ and $\mathrm{Y}$ directions.

The main goal of a FEA is to examine how a structure or component responds to certain loading conditions. Specifying the proper loading condition is
After load application, the post processing procedure begins, It means reviewing the results of an analysis, it is probably the most important step in the analysis, because, it is trying to understand how applied loads affect the design, how good the finite element mesh is, and so on... The results of this study is represented by the equivalent Von Mises stress at selected nodes.

The mean of Three different nodes were selected on root surface except the apex were four nodes are choosen like the following:

A mesial cervical area

$B$ mesial middle root surface area

$\mathrm{C}$ apical area

D distal middle root surface area

E distal cervical root surface area 


\section{RESULTS}

Table (3): The comparison among the three metals (Cobalt-Chromium, Gold, and Titanium).

\begin{tabular}{|c|c|c|c|c|c|c|c|}
\hline \multirow[b]{2}{*}{ Groups } & \multirow[b]{2}{*}{ load } & \multirow{2}{*}{$\begin{array}{c}\text { Mean } \\
\text { Stress } M P a\end{array}$} & \multirow[b]{2}{*}{$S D$} & \multicolumn{2}{|c|}{95 C.I. } & \multirow[b]{2}{*}{ Minimum } & \multirow[b]{2}{*}{ Махімит } \\
\hline & & & & $\begin{array}{l}\text { Lower } \\
\text { bound }\end{array}$ & $\begin{array}{l}\text { Upper } \\
\text { bound }\end{array}$ & & \\
\hline \multirow{3}{*}{ (Area a) } & $\mathrm{C}$ & 5.60233 & 2.03501 & 0.54709 & 10.65757 & 3.47 & 7.53 \\
\hline & G & 5.57267 & 2.62051 & -0.93704 & 12.08237 & 2.72 & 7.87 \\
\hline & $\mathrm{T}$ & 5.36667 & 1.64418 & 1.28229 & 9.45104 & 3.50 & 6.60 \\
\hline \multirow{3}{*}{ (Area b) } & $\mathrm{C}$ & 21.38767 & 2.59990 & 14.92915 & 27.84619 & 18.5 & 23.6 \\
\hline & G & 22.92100 & 2.46894 & 16.78782 & 29.05418 & 20.2 & 24.9 \\
\hline & $\mathrm{T}$ & 22.66667 & 2.48261 & 16.9953 & 28.83380 & 19.9 & 24.7 \\
\hline \multirow{3}{*}{ (Area c) } & $\mathrm{C}$ & 32.03725 & 23.09773 & -4.71639 & 68.79089 & 15.7 & 65.3 \\
\hline & G & 31.32825 & 22.06511 & -3.78227 & 66.43877 & 14.5 & 63.5 \\
\hline & $\mathrm{T}$ & 33.57500 & 20.36064 & 1.17667 & 65.97333 & 19.5 & 63.7 \\
\hline \multirow{3}{*}{ (Area d) } & $\mathrm{C}$ & 40.55667 & 2.56436 & 34.18644 & 46.92689 & 38.1 & 43.2 \\
\hline & G & 41.86400 & 2.22102 & 36.34668 & 47.38132 & 39.8 & 44.2 \\
\hline & $\mathrm{T}$ & 41.60000 & 2.26495 & 35.97355 & 47.22645 & 39.5 & 44.0 \\
\hline \multirow{3}{*}{ (Area e) } & $\mathrm{C}$ & 3.98467 & 1.70936 & -0.26161 & 8.23094 & 2.01 & 4.99 \\
\hline & G & 4.00000 & 1.83229 & -0.55167 & 8.55167 & 1.89 & 5.19 \\
\hline & $\mathrm{T}$ & 3.96667 & 1.79258 & -0.48634 & 8.41968 & 1.90 & 5.10 \\
\hline
\end{tabular}

C=Cobalt-Chromium , G=Gold , T=Titanium

\begin{tabular}{|c|c|c|c|c|c|c|}
\hline & & Sum of squares & $d f$ & Mean square & $F$ & Significant \\
\hline \multirow{3}{*}{ (Area a) } & Between groups & 0.09885 & 2 & \multirow{3}{*}{$\begin{array}{c}0.04943 \\
4.571\end{array}$} & \multirow{3}{*}{0.001} & \multirow{3}{*}{0.989} \\
\hline & Within group & 27.423 & 6 & & & \\
\hline & Total & 27.522 & 8 & & & \\
\hline \multirow{3}{*}{ (Area b) } & Between groups & 4.052 & 2 & \multirow{3}{*}{$\begin{array}{l}2.026 \\
6.339\end{array}$} & \multirow{3}{*}{0.320} & \multirow{3}{*}{0.738} \\
\hline & Within group & 38.037 & 6 & & & \\
\hline & Total & 42.089 & 8 & & & \\
\hline \multirow{3}{*}{ (Area c) } & Between groups & 10.554 & 2 & \multirow{3}{*}{$\begin{array}{c}5.277 \\
478.310\end{array}$} & \multirow{3}{*}{0.011} & \multirow{3}{*}{0.989} \\
\hline & Within group & 4304.790 & 6 & & & \\
\hline & Total & 4315.344 & 8 & & & \\
\hline \multirow{3}{*}{ (Area d) } & Between groups & 2.867 & 2 & \multirow{3}{*}{$\begin{array}{c}1.434 \\
5.56\end{array}$} & \multirow{3}{*}{0.258} & \multirow{3}{*}{0.780} \\
\hline & Within group & 33.278 & 6 & & & \\
\hline & Total & 36.145 & 8 & & & \\
\hline \multirow{3}{*}{ (Area e) } & Between groups & 0.00167 & 2 & \multirow{3}{*}{$\begin{array}{c}0.000835 \\
3.164\end{array}$} & \multirow{3}{*}{0.000} & \multirow{3}{*}{1.000} \\
\hline & Within group & 18.985 & 6 & & & \\
\hline & Total & 18.987 & 8 & & & \\
\hline
\end{tabular}

ANOVA

LSD

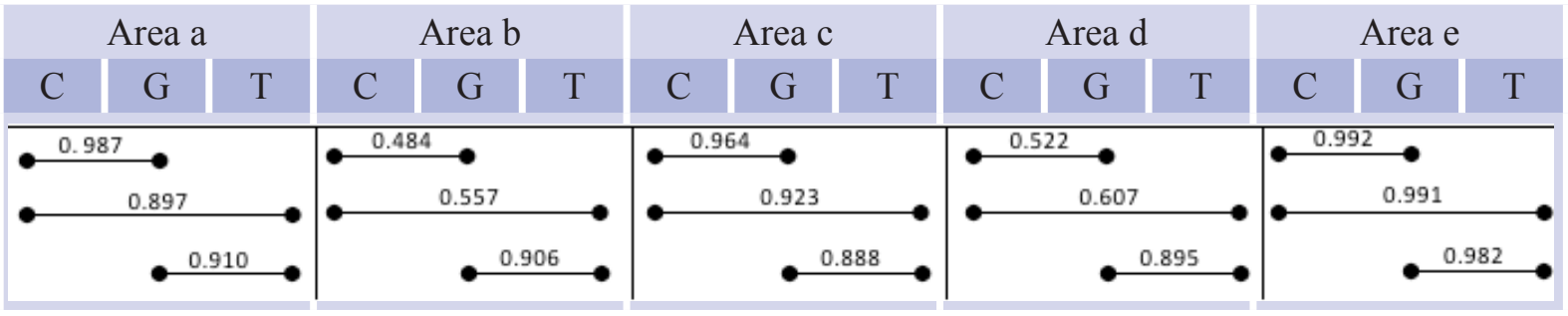


The maximum equivalent stress value were was no significant difference among the three metals very close to each other, although gold and titanium in all, cervical, middle third or apical areas of root showed a slight increase in mean stress values for the surface as shown in Table (3).

apical and middle third areas. But statistically there

Table (4): The comparison among the three designs (RE-D, RE-M, and RE-MD) when pressure is applied on the saddle area in reduced bone support.

\begin{tabular}{|c|c|c|c|c|c|c|c|}
\hline \multirow{2}{*}{ Groups } & \multirow{2}{*}{ load } & \multirow{2}{*}{$\begin{array}{c}\text { Mean Stress } \\
\qquad M P a\end{array}$} & \multirow{2}{*}{ SD } & \multicolumn{2}{|c|}{95 C.I. } & \multirow{2}{*}{ Minimum } & \multirow{2}{*}{ Maximum } \\
\hline & & & & Lower bound & Upper bound & & \\
\hline \multirow{3}{*}{ (Area a) } & RE-D2 & 6.165 & 0.737 & 4.333 & 7.997 & 5.33 & 6.71 \\
\hline & RE-M2 & 13.657 & 7.880 & -5.618 & 33.532 & 8.56 & 23.0 \\
\hline & RE-MD2 & 5.790 & 2.431 & -0.250 & 11.831 & 3.31 & 8.16 \\
\hline \multirow{3}{*}{ (Area b) } & RE-D2 & 15.566 & 0.888 & 13.360 & 17.772 & 14.954 & 16.588 \\
\hline & RE-M2 & 17.962 & 0.915 & 15.687 & 20.237 & 17.301 & 19.008 \\
\hline & RE-MD2 & 15.132 & 0.552 & 14.559 & 17.304 & 15.488 & 16.551 \\
\hline \multirow{3}{*}{ (Area c) } & RE-D2 & 18.840 & 8.173 & 5.835 & 31.845 & 12.484 & 30.719 \\
\hline & RE-M2 & 19.153 & 8.051 & 6.341 & 31.964 & 10.301 & 29.831 \\
\hline & RE-MD2 & 18.788 & 12.158 & -0.557 & 38.135 & 10.159 & 36.126 \\
\hline \multirow{3}{*}{ (Area d) } & RE-D2 & 25.2000 & 1.860 & 20.578 & 29.821 & 23.707 & 27.284 \\
\hline & RE-M2 & 24.570 & 1.923 & 19.793 & 29.347 & 22.375 & 25.957 \\
\hline & RE-MD2 & 27.461 & 3.237 & 19.417 & 35.504 & 23.752 & 29.723 \\
\hline \multirow{3}{*}{ (Area e) } & RE-D2 & 5.820 & 4.585 & -5.570 & 17.210 & 2.664 & 11.080 \\
\hline & RE-M2 & 7.601 & 6.773 & -9.223 & 24.427 & 2.251 & 15.217 \\
\hline & RE-MD2 & 5.379 & 2.700 & -1.328 & 12.087 & 3.049 & 8.339 \\
\hline
\end{tabular}

ANOVA

\begin{tabular}{|c|c|c|c|c|c|c|}
\hline & & Sum of squares & df & Mean square & $\mathrm{F}$ & Significant \\
\hline \multirow{3}{*}{ (Area a) } & Between groups & 127.50 & 2 & \multirow{3}{*}{$\begin{array}{l}63.770 \\
22.851\end{array}$} & \multirow{3}{*}{2.791} & \multirow{3}{*}{0.139} \\
\hline & Within group & 137.106 & 6 & & & \\
\hline & Total & 264.646 & 8 & & & \\
\hline \multirow{3}{*}{ (Area b) } & Between groups & 10.000 & 2 & \multirow{3}{*}{$\begin{array}{l}5.000 \\
0.644\end{array}$} & \multirow{3}{*}{7.759} & \multirow{3}{*}{0.22} \\
\hline & Within group & 3.866 & 6 & & & \\
\hline & Total & 13.866 & 8 & & & \\
\hline \multirow{3}{*}{ (Area c) } & Between groups & 0.311 & 2 & \multirow{3}{*}{$\begin{array}{c}0.155 \\
93.147\end{array}$} & \multirow{3}{*}{0.002} & \multirow{3}{*}{0.998} \\
\hline & Within group & 838.323 & 6 & & & \\
\hline & Total & 838.634 & 8 & & & \\
\hline \multirow{3}{*}{ (Area d) } & Between groups & 13.865 & 2 & \multirow{3}{*}{$\begin{array}{l}6.932 \\
5.881\end{array}$} & \multirow{3}{*}{1.179} & \multirow{3}{*}{0.370} \\
\hline & Within group & 35.285 & 6 & & & \\
\hline & Total & 49.149 & 8 & & & \\
\hline \multirow{3}{*}{ (Area e) } & Between groups & 8.305 & 2 & \multirow{3}{*}{$\begin{array}{c}4.152 \\
24.731\end{array}$} & \multirow{3}{*}{0.168} & \multirow{3}{*}{0.849} \\
\hline & Within group & 148.387 & 6 & & & \\
\hline & Total & 156.692 & 8 & & & \\
\hline
\end{tabular}

LSD

\begin{tabular}{|c|c|c|c|c|c|c|c|c|c|c|c|c|c|c|}
\hline \multicolumn{3}{|c|}{ Area a } & \multicolumn{3}{|c|}{ Area b } & \multicolumn{3}{|c|}{ Area c } & \multicolumn{3}{|c|}{ Area d } & \multicolumn{3}{|c|}{ Area e } \\
\hline RE-D2 & $\begin{array}{l}\text { RE- } \\
\text { M2 }\end{array}$ & $\begin{array}{l}\text { RE- } \\
\text { MD2 }\end{array}$ & RE-D2 & $\begin{array}{l}\text { RE- } \\
\text { M2 }\end{array}$ & $\begin{array}{l}\text { RE- } \\
\text { MD2 }\end{array}$ & RE-D2 & $\begin{array}{l}\text { RE- } \\
\text { M2 }\end{array}$ & $\begin{array}{l}\text { RE- } \\
\text { MD2 }\end{array}$ & RE-D2 & $\begin{array}{l}\text { RE- } \\
\text { M2 }\end{array}$ & $\begin{array}{l}\text { RE- } \\
\text { MD2 }\end{array}$ & RE-D2 & $\begin{array}{l}\text { RE- } \\
\text { M2 }\end{array}$ & $\begin{array}{l}\text { RE- } \\
\text { MD2 }\end{array}$ \\
\hline \multirow{2}{*}{\multicolumn{3}{|c|}{$\bullet \quad 0.093$}} & \multicolumn{3}{|c|}{0.011} & \multicolumn{3}{|c|}{0.964} & \multicolumn{3}{|c|}{0.761} & \multicolumn{3}{|c|}{0.676} \\
\hline & & & & 0.597 & & & 0.994 & & & 0.297 & & & 0.917 & \\
\hline \multicolumn{3}{|c|}{0.081} & \multicolumn{3}{|c|}{0.021} & \multicolumn{3}{|c|}{$\bullet 0.959$} & \multicolumn{3}{|c|}{0.195} & \multicolumn{3}{|c|}{0.604} \\
\hline
\end{tabular}


Results of table (4) shows a decrease of mean stress values in the mesial-distal design compared to the mesial rest design and distal rest design in all areas cervical both mesial and distal side, middle area also mesial and distal side, except the apical area where there is a slight increase in mean stress values

\section{DISCUSSION}

It is possible to use an FEA to ascertain the stress distributions of a subject's interior, which are difficult to measure in an experimental analysis, to extract various physical data such as stress, strain, and displacement, conditions can be set more easily than in other biomechanical investigations. This is the reason why FEAs have been studied in typical biomechanical investigations in recent years ${ }^{(11)}$

A 2-D FEA method was performed in this study, since we are concerned with a very thin layer of bone (cortical bone), so the demand raised for using 2-D because in term of element number it provides a very fine mesh in critical areas which can provide very precise values results.

When comparing the Cobalt-Chromium, Gold, and Titanium metals:

The three metals show no significant difference in stress distribution although the modulus of elasticity of Co-Cr. is about twice that of gold and titanium ${ }^{(10)}$.
But it did not seems to affect the transmission of force, this result will not allow for one material to be superior to other in terms of stress distribution and stress concentration.

The ideal design of an RPD focuses on protecting the abutments and minimizing damage to the residual ridge in an attempt to favorably distribute the occlusal forces on them ${ }^{(12)}$ This is why this study focused on the design of frame work with reduced bone support to prevent further bone loss, results yield that the mesio-distal rest had the least stress values, in other words is superior to the other two designs as in Figure (3). This agrees with Sulik and White 1981 (13) that "when the masticator system is altered by the loss of teeth and supporting bone, the distribution of stresses is altered". This can be explained that, due to the external load there are direct and bending stresses. The direct stress is a compression stress while the stress due to the bending moment is a linear distributed cross the investigated area as shown in Figure (4). So for the mesio-distal rest design there are two external forces applied at opposite side of the tooth. The bending moment due to one of the two forces will eliminate the bending moment of the other force, so the effected force will only be the remainder compressive force ${ }^{(14,15)}$.

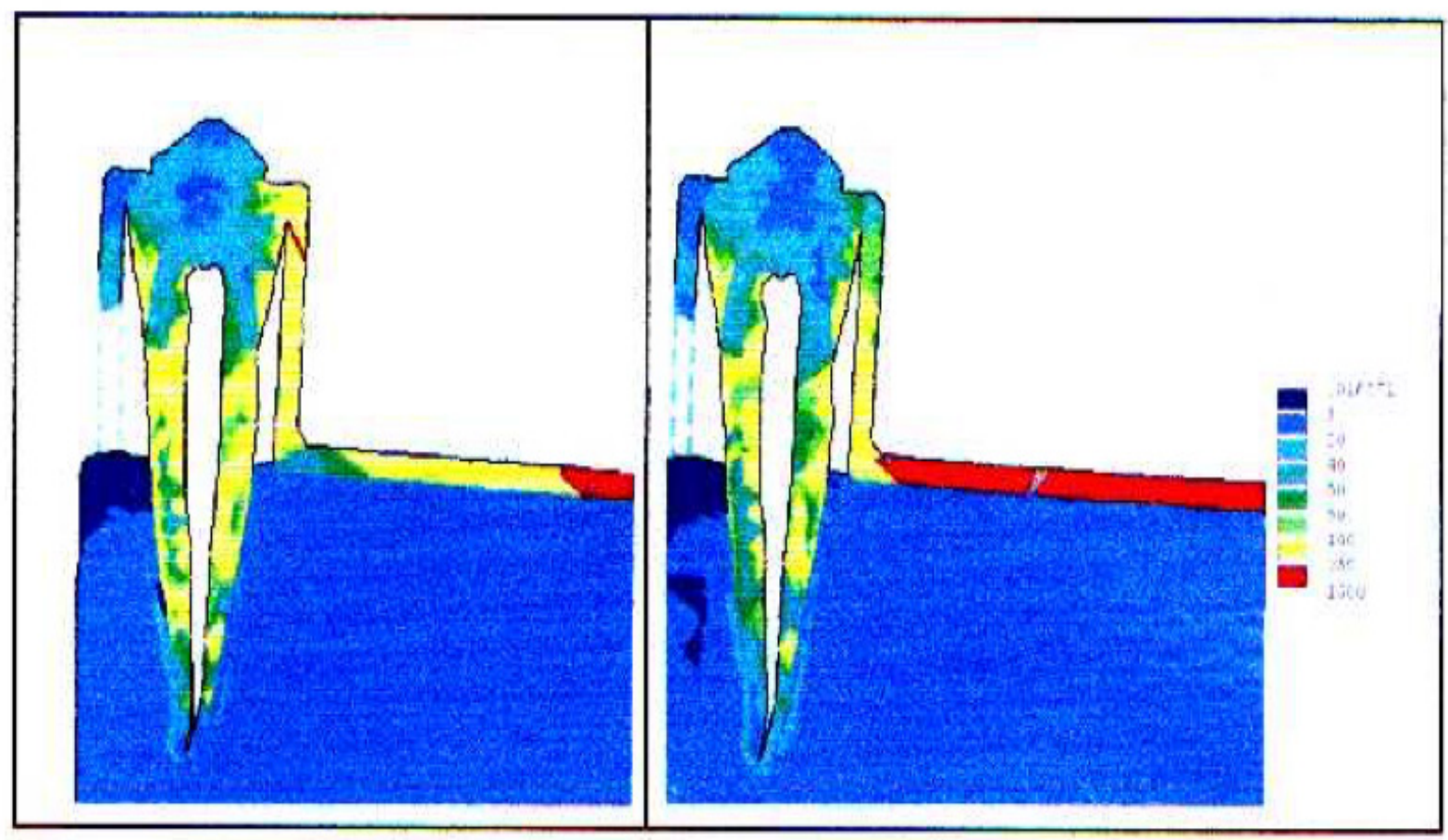

Figure (3) Distribution of the equivalent Von Mises stress contour for the mesio-distal rest design. 


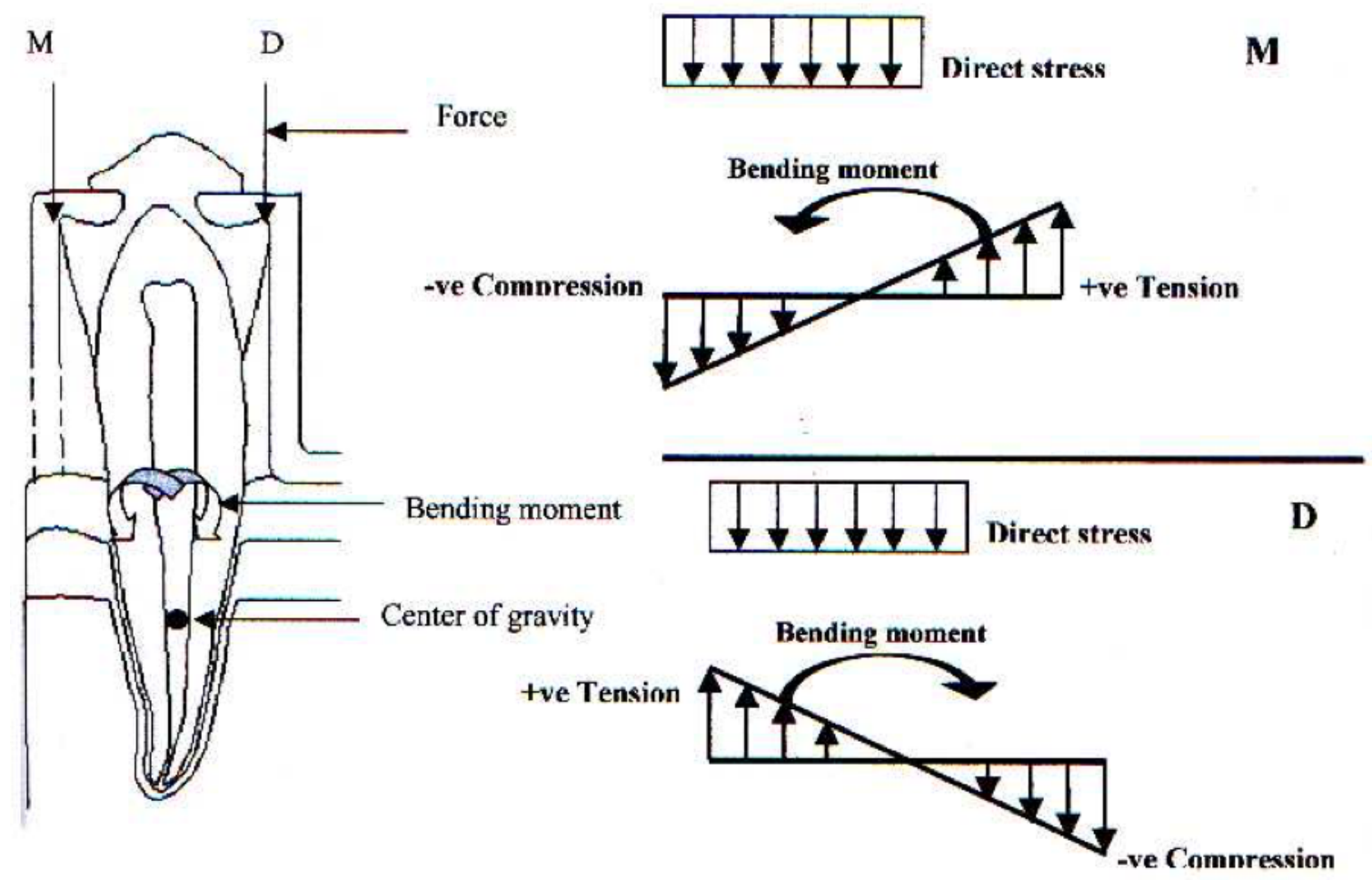

Figure(4) schematic drawing of type of stresses generated from loading the tooth.

\section{REFERENCES:}

1. Anda Slaidina, Una Soboleva,Bone Mineral Density and Mandibular Residual Ridge Resorption The International journal of prosthodontics, 2014;27:270-276.

2. E. Zmysłowska, S. Ledzion, K. Jędrzejewski Factors affecting mandibular residual ridge resorption in edentulous patients: a preliminary report, Folia Morphol.2007; 66( 3): 346-352.

3. Li Shue, Richard J. Miron, and Zhang Yufeng. Review of Implant Support for the Distal Extension Removable Partial Dentures. JSM Dent Surg.2016; 1(1): 1007.

4. C.M, ARCHANGELO, E.P, ROCHA2, J. A PEREIRA, M. M JUNIOR, R .B ANCHIETA, A .C FREITAS JÚNIOR. Periodontal ligament influence on the stress distribution in a removable partial denture supported by implant: a finite element analysis. J Appl Oral Sci.2012;20(3):362-8.

5. J Żmudzki, G Chladek, and J Kasperski Biomechanical factors related to occlusal load transfer in removable complete dentures. Biomech Model Mechanobiol.2015; 14(4): 679-691.

6. O Pal Singh, R Kaur, S Madaan Nanda, E Sethi. Residual ridge resorption: A major oral disease entity in relation to bone density. Indian J Oral Sci .2016;7: 3-6.

7. Yang, Lang, Felton. Finite element stress analysis on the effect of splitting in fixed partial dentures. J Prosthet Dent 1999; 81(6): 721-728.

8. Sato Y, Tsuga K, Abe Y, Akagawa Y. Finite element analysis of the effect of vertical curvature on half oval cast clasps. J Oral Rehabilit 1999; 26:554-558.

9. O'Grady J, Sherif M, Likeman P. A finite element analysis of a mandibular canine as a denture abutment. Eur J Prosthodontic Rest. Dent 1996; 4(3): 117-121.

10. Craig G. Restorative dental materials. Tenth edition. Mosby. 1997.

11. M. Omori, Y. Sato, N. Kitagawa, Y. Shimura and Manabu Ito. A biomechanical investigation of mandibular molar implants: reproducibility and validity of a finite element analysis model. International Journal of Implant Dentistry
2015;1:10.

12. HUEY-ER LEE JU-HUI WU CHAU-HSIANG WANG TING-HSUN LAN J E-KANG DU. Biomechanical analysis of distal extension removable partial dentures with different retainers. J Dent Sci.2008; 3(3) $\square$ 133-139.

13. Sulik W. and White J. Modification of stresses surrounding abutment teeth for fixed partial dentures induced by various levels of periodontal support: a photoelastic study. J Prosthet Dent 1981;46(1):32-35.

14. Shear Force And Bending moment UTM. Research University.

15. M. S. Sivakumar. Indian Institute of Technology Madras. 